\title{
Restricted TCR V $\beta$ gene expression and enterovirus infection in Type I diabetes: a pilot study
}

\author{
P. Luppi ${ }^{1}$, M.M.Zanone ${ }^{1}$, H.Hyoty ${ }^{2}$, W. A. Rudert ${ }^{1}$, C.Haluszczak ${ }^{1}$, A.M. Alexander ${ }^{1}$, S. Bertera ${ }^{1}$, D. Becker ${ }^{3}$, \\ M. Trucco ${ }^{1}$ \\ ${ }^{1}$ Division of Immunogenetics, Department of Pediatrics, Rangos Research Center, Children's Hospital of Pittsburgh, \\ University of Pittsburgh, School of Medicine, Pittsburgh, Pennsylvania, USA \\ ${ }^{2}$ Department of Virology, Tampere University Hospital, University of Tampere School of Medicine, Tampere, Finland \\ ${ }^{3}$ Division of Endocrinology, Diabetes and Metabolism, Department of Pediatrics, Children's Hospital of Pittsburgh, \\ University of Pittsburgh, School of Medicine, Pittsburgh, Pennsylvania, USA
}

\section{Abstract}

Aims/hypothesis. High frequencies of T-cell receptor (TCR) $V \beta 7^{+} \mathrm{T}$ cells were detected among the lymphocytes isolated from pancreatic islets of children at the onset of Type I (insulin-dependent) diabetes mellitus. We assessed whether a preferential expression of certain TCR $V \beta$ gene families could also be detected among the peripheral blood mononuclear cells from diabetic patients.

Methods. T-cell receptor repertoires were evaluated by using a semi-quantitative RT-PCR-based technique and confirmed by FACS analysis in peripheral blood mononuclear cells from diabetic patients before, at and after onset of the disease. These patients were also tested for exposure to enteroviruses by RT-PCR and by measuring titres of enterovirus-specific antibodies of the $\operatorname{Ig} \mathrm{A}, \operatorname{IgG}$, and $\operatorname{IgM}$ classes.

Results. T-cell receptor $V \beta 7$ gene family values were higher in recently-diagnosed diabetic patients $(10.5 \% \pm 3.7)$ than in age-matched non-diabetic con- trol subjects $(5.1 \% \pm 1.6)(p<0.001)$. In a timecourse analysis of people who developed diabetes during clinical monitoring (i. e., converters), T-cell receptor $V \beta 7$ gene expression showed values consistently above $10 \%(p<0.0005)$. Long-standing diabetic patients showed lower percentage of $V \beta 7$ expression compared to values measured at disease onset. In the longitudinal study of the converters, multiple acute enterovirus infections were also detected. These infections appeared to be temporally related to increased percentage of $V \beta 7$ gene transcripts.

Conclusion/interpretation. The deviation in the T-cell receptor $V \beta$ repertoire among circulating $\mathrm{T}$ cells from diabetic patients seems to re-emphasize the importance of enterovirus infections in accelerating the progression of Type I diabetes. [Diabetologia (2000) 43: 1484-1497]

Keywords Type I diabetes, etiology, autoimmunity, Coxsackievirus, $\mathrm{T}$ cell receptor.
Type I (insulin-dependent) diabetes mellitus is an autoimmune disease characterized by infiltrating lym-

Received: 16 June 2000 and in revised form: 4 September 2000

Corresponding author: Massimo Trucco, MD, Children's Hospital of Pittsburgh, Rangos Research Center, 3460 Fifth Avenue, Pittsburgh, PA 15213, USA

Abbreviations: TCR, T-cell receptor; $V \beta$, variable region of the gene encoding the TCR $\beta$ chain; $C \alpha$, constant region of the gene encoding the TCR $\alpha$ chain; $C \beta$, constant region of the gene encoding the TRC $\beta$ chain; PBMC, peripheral blood mononuclear cells; RT, reverse-transcriptase; PCR, polymerase chain reaction; $\mathrm{EV}$, enterovirus; $\mathrm{CVB}$, coxsackievirus $\mathrm{B}$; mRNA, messenger RNA; ICA, islet cell antibodies. phocytes in the Langerhans' islets and by destruction of insulin-producing beta cells [1]. Despite many years of intensive studies, the precise cause and mechanisms triggering the beta-cell-specific attack still remain undetermined. The less than $50 \%$ concordance for the disease between monozygotic twins suggests, however, that a complex interplay occurs between genetic and non-genetic factors (i.e., environmental) [2,3]. In particular, epidemiological evidence supports a role for infectious agents in the development and/or progression of Type I diabetes [4-10].

Although the possibility of a virus-mediated etiopathogenesis of Type I diabetes still remains a central point of discussion, certain viral infections, especially 
those caused by enterovirus (EV), have long been considered associated with beta-cell damage [11-13] and with the clinical onset of diabetes [4-15], particularly amongst very young children [15-19]. Genetically-susceptible subjects with autoimmune markers of beta-cell damage (i.e., autoantibodies) develop Tcell responses against EV antigens and EV-infected cells $[12,20,21]$. The relation between antibodies detected and the increased prevalence of Coxsackievirus $B(C V B)$ infection in recently-diagnosed diabetic patients compared with healthy subjects is, however, often inconsistent $[6,10,14,18,19,21]$, as we also found in our previous studies [22-25]. Although, in mice and primates, infection of CVB4 has been shown to induce diabetes [26, 27], the direct association of EV infections and the disease was documented in humans, in only a few anecdotal cases where a CVB4 strain was isolated from the pancreas of a diabetic child [28] and viral RNA sequences were detected in blood samples from children and adults at the onset of Type I diabetes [15, 16, 29].

Several studies proposed Coxsackievirus infection as an environmental trigger for the development of a T-cell autoreactivity by a mechanism of molecular mimicry [30] or by inducing a bystander effect on autoreactive T cells [31]. It has been shown that the timing of a Coxsackievirus infection, rather than a simple documentation of its presence or absence, has important implications in the development of diabetes in NOD mice. In this animal model, CVB4 infection can accelerate the development of Type I diabetes only after a critical amount of autoreactive $\mathrm{T}$ cells have accumulated at the periphery of the islets [32]. Based on this finding, we suppose that in humans, like in rodents, the timing of a Coxsackievirus infection is a critical factor in the development of diabetes by activating autoreactive $\mathrm{T}$ cells already present in the circulation and possibly in proximity to the islets.

It is generally believed that the destruction of the beta-cells producing insulin occurs over a prolonged period of time, eventually resulting in the delayed onset of the disease [1]. During this period, detection of serum antibodies [33-35] and T-cell sensitization [36] to a vast array of islet-cell antigens signifies the presence of autoimmunity even at early stages in the course of the disease. The analysis of the T-cell receptor (TCR) repertoire of the circulating T cells is important because it might represent a direct means to ascertain the presence of $\mathrm{T}$ cells involved in the pathogenesis of Type I diabetes eventually infiltrating the pancreatic islets of Langherans. In humans, it is not possible to actually dissect the kinetics of betacell destruction because specimens from diseased pancreata at different time-points can not be easily obtained. In a previous study, TCR $V \beta 7$ mRNA was, however, expressed by the majority of the islet infiltrating lymphocytes from two children at the onset of Type I diabetes [37].
We assessed the possibility of showing the skewing of the TCR $V \beta$ repertoire by testing the lymphocytes in the peripheral blood from diabetic patients and of founding whether there is a preferential expression of certain TCR $V \beta$ gene families at different timepoints before, at and after the onset of the disease. Accordingly, we evaluated the use of TCR $V \beta$ expression in a group of recently-diagnosed diabetic patients and in a longitudinal prospective study using a group of high-risk first-degree relatives. Some of these relatives eventually developed Type I diabetes (i.e., converters to diabetes) while others did not (i. e., high-risk subjects). The T-cell receptor $V \beta$ expression was also analysed in an additional group of patients who were suffering from diabetes from 2 to 10 years (i.e., long-standing diabetic patients). Moreover, selective $V \beta 7^{+}$T-cell expansion in response to CVB antigens was ascertained in PBMC of non-diabetic control subjects by flow cytometry analysis. Finally, we assessed if there was any evidence of acute EV infections in the subjects by testing their sera for the presence of EV-RNA and of $\operatorname{IgA}, \operatorname{IgG}$ and $\operatorname{IgM}$ class antibodies against EV.

\section{Materials and methods}

Subjects. Twenty-three recently-diagnosed (i.e., within one week of the first insulin injection) children with Type I diabetes (mean age 9.4 years \pm 3.8 ; range $2-16$ years; 11 male : 12 female) were consecutively selected from those treated in the Diabetes Center at the Children's Hospital of Pittsburgh (CHP) in July 1996 to July 1998. As part of a prospective study of risk factors of Type I diabetes, we collected peripheral blood mononuclear cells (PBMC) at serial time points, before, at and after the onset of the disease from four high-risk subjects who eventually developed the disease (i.e., converters to diabetes) (mean age at diagnosis 9.2 years \pm 2.6 ; range $7-13$ years; 2 male : 2 female) and in four others who have not yet developed the disease (i.e., high-risk subjects) (mean age at the first blood sample taken 21.5 years \pm 10.4 ; range $11-35$ years; 2 male : 2 female). In addition, fourteen patients ( 2 siblings included) with long-standing Type I diabetes (mean: 7.2 years \pm 3.4 ; mean age at diagnosis 6.1 years \pm 3.1 ; range $1-11$ years; 6 male : 8 female) were studied. Demographic and clinical data of the subjects studied are summarized in Table 1. These subjects were first-degree relatives of Type I diabetic probands, carried HLA haplotypes conferring susceptibility and had ICA (detected by immunohistochemistry) [33, 34], anti-GAD or anti-ICA512 autoantibodies (detected by radioimmunoassay) or both [35]. Two of the high-risk subjects had borderline, one normal and one low insulin responses to intravenous glucose tolerance but all had normal glycated haemoglobin and plasma glucose concentrations.

The control group consisted of sixteen subjects age-matched and sex-matched to the recently diagnosed diabetic patients (mean age 10.2 years \pm 4.7 ; range $3-16$ years; 9 male : 7 female), recruited amongst patients undergoing orthopedic interventions at CHP. An additional group of thirteen healthy adults age-matched and sex-matched to the high-risk subjects (mean age 39 years \pm 8.5 ; range $23-49$ years; 5 male : 8 female) was also included. None of the control subjects had a family 
Table 1. Demographic and clinical data of subjects studied

\begin{tabular}{|c|c|c|c|c|}
\hline Subjects & Number & Time of onset & $\begin{array}{l}\text { Mean age } \\
\text { at diagnosis (years) }\end{array}$ & $\begin{array}{l}\text { Sex } \\
\text { (Male : Female) }\end{array}$ \\
\hline Recently-diagnosed & 23 & Within 1 week & $\begin{array}{l}9.4 \pm 3.8 \\
\text { (range 2-16) }\end{array}$ & $11: 12$ \\
\hline Converters & 4 & From -40 months to +7 years & $\begin{array}{l}9.2 \pm 2.6 \\
\text { (range } 7-13 \text { ) }\end{array}$ & $2: 2$ \\
\hline High-Risks & 4 & $\begin{array}{l}\text { Non-diabetics studied } \\
\text { at time points eight years apart }\end{array}$ & $\begin{array}{l}21.5 \pm 10.4 \\
(\text { range } 11-35)^{\mathrm{a}}\end{array}$ & $2: 2$ \\
\hline
\end{tabular}

${ }^{a}$ At the time of the first sample collection

history of diabetes and all were negative for ICA, anti-GAD or anti-ICA512 autoantibodies or both. Specimens from these subjects were also used for the in vitro stimulation studies with CVB-infected HeLa cell lysates.

Molecular HLA typing was done in all subjects for whom the cDNA was available (Table 2) [38, 39]. Informed consent was obtained from each subject participating in this study, approved by the Institutional Review Board of the Children's Hospital of Pittsburgh.

Isolation and culture conditions of peripheral blood mononuclear cells $(P B M C)$. Venous blood was drawn in heparinized tubes and processed for PBMC isolation using a Ficoll-Hypaque gradient (1-Step Lymphoprep, Accurate Chemical \& Scientific Corporation, Westbury, N.Y., USA) within a few hours from blood collection. Total RNA was extracted from PBMC obtained from the recently-diagnosed diabetic patients and control subjects, while PBMC from the other subjects were frozen in freezing medium (Gibco BRL Life Technologies, Gaithersburg, Md., USA) and kept in liquid nitrogen until used. To increase the production of functional TCR mRNA, frozen PBMC were stimulated with anti-CD3 (Beckman Coulter, Fullerton, Calif., USA) and recombinant interleukin-2 (rIL-2) (a kind gift from Dr. M. T. Lotze). Frozen PBMC were briefly thawed in RPMI-1640 medium (Gibco BRL) and centrifuged at $1200 \mathrm{rpm}$ for $8 \mathrm{~min}$. Cells were then resuspended in RPMI-1640 medium (Gibco BRL) supplemented with $5 \%$ human AB serum (Normolcera-Plus, Miami, Fla., USA) with addition of $5 \mathrm{U} / \mathrm{ml}$ of rIL-2 and plated at a concentration of $1 \cdot 10^{6}$ cells a well into flat-bottom 24 -well culture plates (Corning, New York, N. Y., USA). Viability of the cells was checked by Trypan blue exclusion and was estimated to be approximately 80 to $90 \%$ in all samples. Peripheral blood mononuclear cells were cultured overnight at $37^{\circ} \mathrm{C}$ in $5 \% \mathrm{CO}_{2}$ in an incubator. The next day, anti-CD3-coated plates were prepared using $100 \mathrm{ng} / \mathrm{ml}$ anti-CD3 (Beckman Coulter) in each plate and then incubated at $37^{\circ} \mathrm{C}$ for at least one hour. After removing unbound antibody, PBMC were transferred to the anti-CD3 treated plates, centrifuged at $500 \mathrm{rpm}$ for $5 \mathrm{~min}$ and returned to the incubator for 2 days. On day 3, rIL-2 at a final concentration of $20 \mathrm{U} / \mathrm{ml}$ was added to each well and the plates were returned to the incubator for 1 day. On the 4th day of the in vitro culture, cells were harvested, pelletted, counted and total RNA was extracted.

Preparation of RNA and synthesis of $c D N A$. Total cytoplasmic RNA was extracted from the PBMC from the various subjects using TRIZOL Reagent according to the manufacturer's instructions (Gibco BRL). All RNA samples were maintained in $75 \%$ ethanol and stored at $-80^{\circ} \mathrm{C}$ until cDNA synthesis was carried out. For each preparation, at least $3 \mu \mathrm{g}$ of total RNA were reverse-transcribed (RT-PCR) into single-stranded cDNA using SUPERSCRIPT II (Gibco BRL).

Evaluation of $T C R^{*} V \beta$ repertoires. The study of the TCR-V $\beta$ gene segment expression required individual amplification of at least 26 TCR- $V \beta$ families and subfamilies [40, 41] using a panel of 5 ' $-V \beta$ primers together with a 6-carboxyfluorescein (6-FAM, Applied Biosystems, Foster City, Calif., USA) 3'- $C \beta$ oligonucleotide. The $V \beta$ and $C \beta$ oligonucleotide primers were used at a final concentration of $0.5 \mu \mathrm{mol} / \mathrm{l}$ each in the $50 \mu \mathrm{l}$ final reaction mixture. As an internal positive control for each $V \beta$ family segment, a pair of constant region oligonucleotides 5'- $C \alpha$ and 3'-C $\alpha$, also tagged with 4,7,2',7'-Tetrachloro-6-carboxyfluorescein, (6-TET; Applied Biosystems), were used at a final concentration of $0.2 \mu \mathrm{mol} / 1$ [40, 41]. Twenty-eight cycles of PCR were carried out to remain in the exponentially increasing part of the reaction [42]. Polymerase chain reaction (PCR) conditions were as follows: denaturation at $94^{\circ} \mathrm{C}$ for $30 \mathrm{~s}$, primer annealing at $60^{\circ} \mathrm{C}$ for $30 \mathrm{~s}$ and primer extension at $70^{\circ} \mathrm{C}$ for $45 \mathrm{~s}$.

Two microliters of the PCR products, corresponding to the TCR $V \beta$ gene families, were resolved by electrophoresis on a $16-\mathrm{cm}, 5 \%$ polyacrylamide non-denaturing gel for $1 \mathrm{~h}$ on an ABI 377 DNA Sequencer (Applied Biosystems). Each gel was then automatically analysed by GeneScan software (Applied Biosystems) which allows for quantitation of fluorescent peak heights and areas corresponding to each band. The relative abundance of $\mathrm{T}$ cells carrying each $V \beta$ chain transcript was estimated by calculating a ratio of $V \beta$ fluorescent and $C \alpha$ fluorescent areas (the internal positive control) for each $V \beta$ gene family. The percentage of each $V \beta$ gene family expression was computed in relation to the sum of all 26 ratios (i.e., per cent of corrected ratios) according to the following formula:

$\% V \beta_{(i)}=\frac{\text { fluorescence } V \beta_{(\mathrm{i})} / \text { fluorescence } C \alpha_{(\mathrm{i})}}{\sum(\text { fluorescence } V \beta / \text { fluorescence } C \alpha)(1 \ldots 26)} \times 100$

where "i" specifies an individual $V \beta$ family. To ensure reproducibility, two PCRs were independently carried out for the majority of the cDNA samples and the percentage of each $V \beta$ gene family expression calculated using the formula shown above. Average values from the two analyses were then calculated.

The presence of a high frequency of TCR $V \beta 7^{+}$circulating $\mathrm{T}$ cells from recently-diagnosed diabetic patients was also checked by flow cytometry analysis. Briefly, $100 \mu \mathrm{l}$ of whole blood from recently-diagnosed diabetic patients and control subjects was incubated with $20 \mu \mathrm{l}$ of FITC-conjugated monoclonal antibodies specific for various human $V \beta$ chains (Beck- 
Table 2. Analysis of HLA-DR and -DQ haplotypes in young and adult control subjects and recently diagnosed diabetic patients

\begin{tabular}{|c|c|c|c|c|c|}
\hline & $\begin{array}{l}\text { Sex } \\
(M / F)\end{array}$ & $\begin{array}{l}\text { Age } \\
\text { (years) }\end{array}$ & $\begin{array}{l}\text { HLA } \\
\text { DRB1 }\end{array}$ & $\begin{array}{l}\text { HLA } \\
\text { DQA1 }\end{array}$ & $\begin{array}{l}\text { HLA } \\
\text { DQB1 }\end{array}$ \\
\hline \multicolumn{6}{|c|}{ Young control subjects } \\
\hline 1 & M & 10 & - & - & - \\
\hline 3 & M & 15 & 02,11 & 01 & 0501,0602 \\
\hline 4 & M & 14 & 02,01 & 01 & 0501,0502 \\
\hline 5 & M & 8 & 11,12 & 01,05 & 0301,0501 \\
\hline 8 & $\mathrm{~F}$ & 13 & 02,13 & 01 & 0601,0605 \\
\hline 9 & $\mathrm{~F}$ & 10 & - & - & - \\
\hline 10 & $\mathrm{~F}$ & 12 & 11,13 & 05 & 0301,0401 \\
\hline 11 & $\mathrm{M}$ & 15 & 03,04 & 0301,05 & 0201,0302 \\
\hline 12 & $\mathrm{~F}$ & 10 & 11,13 & 01,05 & 0301,0603 \\
\hline 13 & $\mathrm{M}$ & 3 & 09,13 & 01,0301 & 0303,0605 \\
\hline 17 & $\mathrm{~F}$ & 33 & 02,14 & 01,05 & 0301,0502 \\
\hline 18 & $\mathrm{~F}$ & 30 & 02,07 & 01,0201 & 0201,0602 \\
\hline 19 & M & 27 & 07 & 0201 & 0201 \\
\hline 20 & M & 25 & 04,02 & 01,0301 & 0301,0602 \\
\hline 21 & M & 49 & 11,13 & 01,05 & 0301,0603 \\
\hline 22 & M & 49 & 01,07 & 01,0301 & 0301,0501 \\
\hline 23 & M & 34 & 04,07 & 01,03 & 0302,0602 \\
\hline 24 & $\mathrm{~F}$ & 40 & 04,13 & 01,03 & 0302,0603 \\
\hline 25 & $\mathrm{~F}$ & 23 & 03,04 & 03,04 & 0201,0302 \\
\hline 26 & $\mathrm{~F}$ & 37 & 03,04 & 03,04 & 0201,0302 \\
\hline 27 & $\mathrm{~F}$ & 42 & 03,04 & 03,04 & 0301,0302 \\
\hline 28 & $\mathrm{~F}$ & 35 & 03,04 & 03,04 & 0201,0302 \\
\hline 29 & $\mathrm{~F}$ & 45 & 03,04 & 03,04 & 0201,0302 \\
\hline 8 & M & 14 & 04 & 0301 & 0301,0302 \\
\hline 9 & $\mathrm{~F}$ & 13 & - & - & - \\
\hline 10 & M & 13 & - & - & - \\
\hline 11 & M & 14 & 04,07 & 0201, 0301 & 0201 \\
\hline 12 & M & 13 & 03 & 05 & 0201 \\
\hline 13 & M & 2 & - & - & - \\
\hline 14 & M & 8 & 04,13 & 01,0301 & 0302,0602 \\
\hline 15 & $\mathrm{~F}$ & 11 & 03,11 & 05 & 0201,0301 \\
\hline 16 & M & 10 & 04,07 & 0201, 0301 & 0201,0302 \\
\hline 17 & M & 7 & 01,04 & 01,03 & 0501,0302 \\
\hline 18 & $\mathrm{~F}$ & 5 & - & 0201,0501 & 0201, 0301 \\
\hline 19 & $\mathrm{~F}$ & 10 & 03,07 & 0301, 0501 & 0201,0302 \\
\hline 20 & M & 3 & -- & 0102,0301 & 0302,0502 \\
\hline 21 & M & 9 & 02,04 & 01,0301 & 0301,0501 \\
\hline 22 & $\mathrm{~F}$ & 9 & - & - & - \\
\hline 23 & $\mathrm{~F}$ & 7 & - & - & - \\
\hline
\end{tabular}

Molecular typing for alleles at HLA-DRB1, DQA1 and DQB1 loci carried out as described previously [38-39]

man Coulter), $20 \mu \mathrm{l}$ of PE-conjugated monoclonal antibody to pan-TCR $\alpha \beta$ (Coulter, Miami, Fla., USA) and $20 \mu \mathrm{l}$ of CyChrome-conjugated monoclonal antibody to the leucocyte common antigen (CD45) (Dako Corporation, Carpinteria, Calif., USA) or appropriate negative isotype control. The samples were stained in the dark for $15 \mathrm{~min}$ and erythrocytes were then lysed with PharMLyse (Pharmingen International,
Becton Dickinson, San Jose, Calif., USA). Samples were then washed twice in FACS media (Hank's balanced salt solution with $0.1 \%$ bovine serum albumin and $0.1 \%$ sodium azide) and stored in $1 \%$ paraformaldheyde (PFA) at $4{ }^{\circ} \mathrm{C}$ until run on a Becton Dickinson FACSCalikur Instrument. T-cell receptor $V \beta$ repertoire analysis by flow cytometry was also done on PBMC from normal healthy donors cultured with uninfected 
and CVB-infected HeLa cell lysates. Briefly, one milliliter of the cell culture was removed, cells were pelletted, resuspended in phosphate buffered saline (PBS) and aliquoted for flow cytometry staining using the panel of monoclonal antibodies as above. The samples were stained in the dark for $15 \mathrm{~min}$, washed twice in FACS media and then stored in $1 \%$ PFA at $4{ }^{\circ} \mathrm{C}$ until run on a Becton Dickinson FACScan instrument.

\section{Infection of HeLa cells with Coxsackievirus B (CVB)}

Coxsackievirus titres. Coxsackievirus B (CVB) was obtained from the ATCC (catalogue No. VR-30) and quantitated by the plaque assay method. Briefly, $95 \%$ confluent HeLa cells were obtained by seeding two 12 -well plates for each isolate with $1.5 \mathrm{ml}$ of cells at $2.5 \cdot 10^{5} / \mathrm{ml}$. Cells became $95 \%$ confluent in one to four days. The media was aspirated and replaced with $0.1 \mathrm{ml} /$ well of serial tenfold dilutions $\left(10^{-3}\right.$ to $\left.10^{-9}\right)$ of the viral stock in minimal essential medium (MEM) (Gibco BRL), in triplicate. After viral adsorption at $37^{\circ} \mathrm{C}$ in $5 \% \mathrm{CO}_{2}$ for 45 to $60 \mathrm{~min}, 1.5 \mathrm{ml} /$ well of $1 \%$ methyl cellulose in MEM was added and the plates incubated for 1-3 days until plaques were visible. The cell layers were stained with crystal violet and the plaques counted.

Preparation of virus stocks and lysates. Confluent monolayers of HeLa cells in T-175 $\mathrm{cm}^{2}$ flasks were used three to four days post passage. The media was aspirated and replaced with $5 \mathrm{ml}$ of Eagle's minimal essential medium (EMEM) (Gibco BRL) supplemented with $10 \%$ fetal calf serum (FCS) containing $3 \cdot 10^{6}$ plaque forming units of a viral stock to achieve a multiplicity of infection (MOI) of about 0.1 . The virus was allowed to absorb at $37^{\circ} \mathrm{C}, 5 \% \mathrm{CO}_{2}$ for 45 to $60 \mathrm{~min}$ and $25 \mathrm{ml}$ of EMEM (Gibco BRL), $10 \%$ FCS was added. The cultures were incubated for three to four days while monitoring cytopathic effect (CPE). At 90 to $100 \%$ CPE, the cells and the media were collected by scraping and then centrifuged at 2000 $\mathrm{rpm}$. The supernatant was aliquoted, stored at $-70^{\circ} \mathrm{C}$ and assayed by plaque titration. For cell lysate production, the medium and cells were collected as described above. Glycine was added to a final concentration of $100 \mathrm{mmol} / \mathrm{l}$ and $\mathrm{pH}$ 9.5. The extract was then sonicated, UV treated, centrifuged as above, aliquoted and stored at $-70^{\circ} \mathrm{C}$. Finally, the lysate was tested by the plaque assay method described above to verify that there was no residual CPE.

In vitro PBMC stimulation with CVB-infected HeLa cell lysates. Peripheral blood mononuclear cells $\left(3 \cdot 10^{6}\right)$ isolated from thirteen non-diabetic donors were seeded in a volume of $3 \mathrm{ml}$ of RPMI-1640 medium (Gibco BRL) supplemented with $10 \%$ human $\mathrm{AB}$ serum (Normolcera Plus), into a $0.2 \mu \mathrm{m}$ ventilation-capped $25 \mathrm{~cm}^{2}$ tissue polystyrene culture flasks and exposed to lysates of CVB-infected HeLa cells (see above). Cultures with lysates of uninfected HeLa cells were used as negative control cells. Peripheral blood mononuclear cells were cultured at $37^{\circ} \mathrm{C}$ in $5 \% \mathrm{CO}_{2}$ for 9 days and independently stimulated with each of the different antigens on day 0 and every 3 days thereafter. Recombinant interleukin-2 (rIL-2) was added $(10 \mathrm{U} / \mathrm{ml})$ on day 4 . Twelve hours before harvesting, rIL-2 $(10 \mathrm{U} / \mathrm{ml})$ was again added to allow regeneration of potentially modulated TCR. At day 5 and $9,1 \mathrm{ml}$ of the in vitro culture was used for TCR repertoire analysis by flow cytometry as described above.

$E V$ - $R N A$ detection by reverse transcriptase ( $R T)-P C R$ and antibody analysis in the serum. Serum samples from the different subjects have been analysed for the presence of EV RNA and EV antibodies. Detection of EV-RNA was done by a RT-PCR method which was carried out from coded samples as described previously [43]. This RT-PCR method amplifies a genome sequence of the highly conserved 5' non-coding region of all EV serotypes and RT-PCR products are identified by a lanthanide chelate labelled EV specific probe in a liquid phase hybridization assay. The detection limit of this assay is $0.015 \mathrm{fg}$ of viral RNA. The IgG and IgA class antibodies to CVB4 antigen and to a synthetic EV peptide were analysed using an enzyme immunoassay (EIA) method described previously [4, 20] and IgM class antibodies using a heavy chain capture EIA using a panel of three EV antigens (CVB3, echovirus 11, and CVA16) [20]. These antibody assays were designed to detect antibodies in several EV serotypes. Virus antigens were also heat-treated at $+56^{\circ} \mathrm{C}$ for $15 \mathrm{~min}$ to expose antigenic determinants which are cross-reactive between different EV serotypes. The antibody results are expressed as enzyme immunoassay units (EIU) which show the relative antibody activity of the sample compared to positive and negative control sera included in each test and which are therefore comparable between different test runs. All serum samples were tested in duplicate. Samples were considered seropositive if EIU was greater than 15. Diagnosis of acute infection during the follow-up in the four converters was based on the presence of a twofold or greater increase in the concentration of $\operatorname{IgA}$ and/or $\mathrm{IgG}$ and/or detection of IgM in amounts exceeding cut-off limits defined previously [4] and/or presence of EV-RNA in serum. The IgM and RT-PCR data are shown as categorical variables and are expressed as $+/$.

Statistical analysis. The percentage of expression of each $V \beta$ gene family is presented as means \pm SD for each study group. For each $V \beta$ gene family, the 100th centile of the appropriate control population was chosen as the upper limit of normal, above which values were considered to be skewed. Differences in the prevalence of skewed $V \beta$ families were assessed using Fischer's exact test. Mean values of $V \beta 7$ and $V \beta 13.1$ gene families were compared between study groups using the MannWhitney $\mathrm{U}$ test. A $p$ value of less than 0.05 was considered statistically significant. Concentrations of enteroviral antibodies between the study groups were compared using the MannWhitney U test.

\section{Results}

$T C R$ repertoire analysis. The estimated percentage of T cells bearing different TCR, extrapolated as a function of the relative abundance of the mRNA from different $V \beta$ gene families, in the peripheral blood of patients recently diagnosed with Type I diabetes is shown in Figure 1. The majority of the patients studied (Table 2) showed a higher abundance of the $V \beta 7$ gene family (mean value $10.5 \% \pm 3.7$ ) compared with the expression pattern observed in the PBMC of age-matched non-diabetic control subjects $(5.1 \% \pm 1.6)(p<0.001)$. Fifteen $(65 \%)$ of the recently-diagnosed diabetic patients had values of $V \beta 7$ above the upper limit of the appropriate control group $(8.3 \%)$ and this prevalence of skewed $V \beta 7$ was statistically higher $(p<0.0005)$ compared with the control subjects. In recently-diagnosed diabetic 


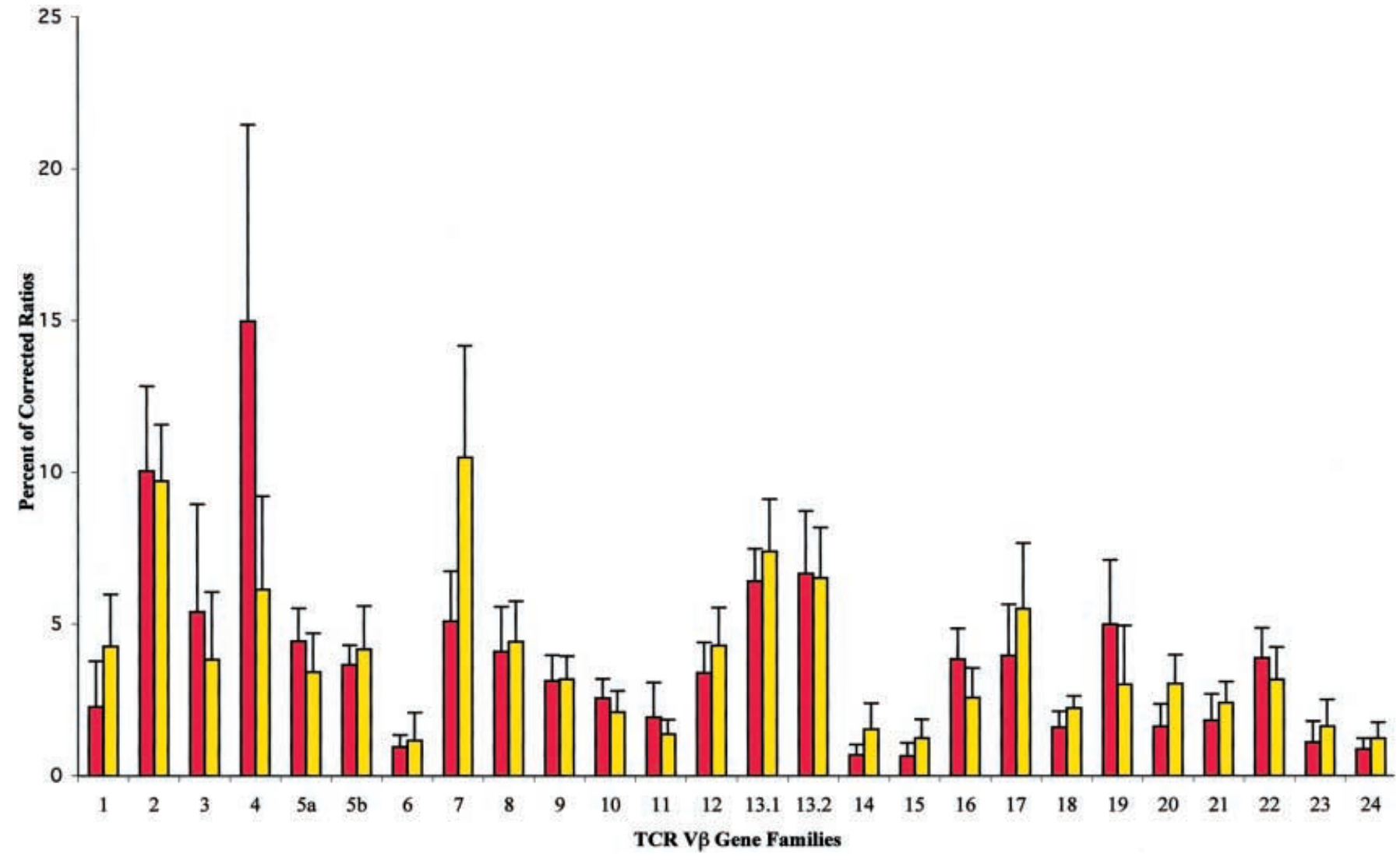

Fig. 1. Analysis of TCR $V \beta$ repertoire in PBMC from recentlydiagnosed Type I diabetic patients $(\square, n=23)$ and age-matched controls $(\square, n=16)$. The value of each TCR $\mathrm{V} \beta$ is expressed as a mean percentage $( \pm \mathrm{SD})$ of corrected ratios. The difference between mean values of $V \beta 7^{+}$T cells from diabetic patients and normal control subjects is statistically significant $(p<0.001)$

patients, other $V \beta$ mRNA gene families, like $V \beta 1$ and $V \beta 17$, tended to be higher than in the control group but failed to reach statistical significance. Among the age-matched control population, the $V \beta 4$ family was the most represented although its percentage varied extensively as shown by the large standard deviation (Fig. 1).

A high frequency of circulating $\mathrm{V} \beta 7^{+} \mathrm{T}$ cells in recently-diagnosed diabetic patients was also confirmed by flow cytometry analysis. Using the only available $\mathrm{V} \beta 7$-specific monoclonal antibody that recognizes the $\mathrm{V} \beta 7.1$ subfamily, the frequency of panTCR $\alpha \beta^{+}$T cells carrying the $\mathrm{V} \beta 7.1$ chain was higher (2.1-5.8\% of TCR $\alpha \beta^{+} \mathrm{T}$ cells) than the frequency for this $\mathrm{V} \beta$ chain detected in non-diabetic subjects (1.6-3.2\% of TCR $\alpha \beta^{+}$cells) (Fig. 2). The difference in raw values of the detected $\mathrm{V} \beta 7$ percentages between the molecular (RT-PCR) and the flow cytometry method could depend on several factors, such as detection of mRNA gene transcripts with one technique and expression of surface protein with the oth- er, specificity of the anti- $\mathrm{V} \beta$ antibody limited to the 7.1 subfamily and the different denominators each method uses for percentage calculations.

In a time-course analysis of the four converters, TCR $V \beta$ gene expression was assessed in blood samples collected from forty months before the onset of the disease to seven years after. The analysis indicated a $V \beta 7$ value consistently above $10 \%$ at all time points and in all patients (Table 3 ). The specificity of this finding for Type I diabetic patients was evident when compared with the range of $V \beta 7$ values in PBMC from age-matched control subjects that were $5.1 \% \pm 1.6$ (highest $8.3 \%$ ) (Table 3 ). All the converters at each time point had values of $V \beta 7$ consistently above the upper limit of the normal control group and this prevalence of skewed $V \beta 7$ was significantly higher $(p<0.0005)$ compared with control subjects. The only exception was a sample collected seven years after the onset from converter No. 3 that showed a value of $V \beta 7$ of $6.3 \%$.

The enrichment in $V \beta 7^{+} \mathrm{T}$ cells did not seem to be affected by the anti-CD3 and IL-2 stimulation of the frozen PBMC because TCR analysis on freshly processed PBMC from the same patients showed that the detected percentage of $V \beta$ gene expression in these two samples correlate very well (data not shown), as reported previously [44].

To rule out the possibility that the skewing in the patients' $V \beta$ repertoire was directly related to HLA alleles, we compared the TCR $V \beta$ repertoire pattern 

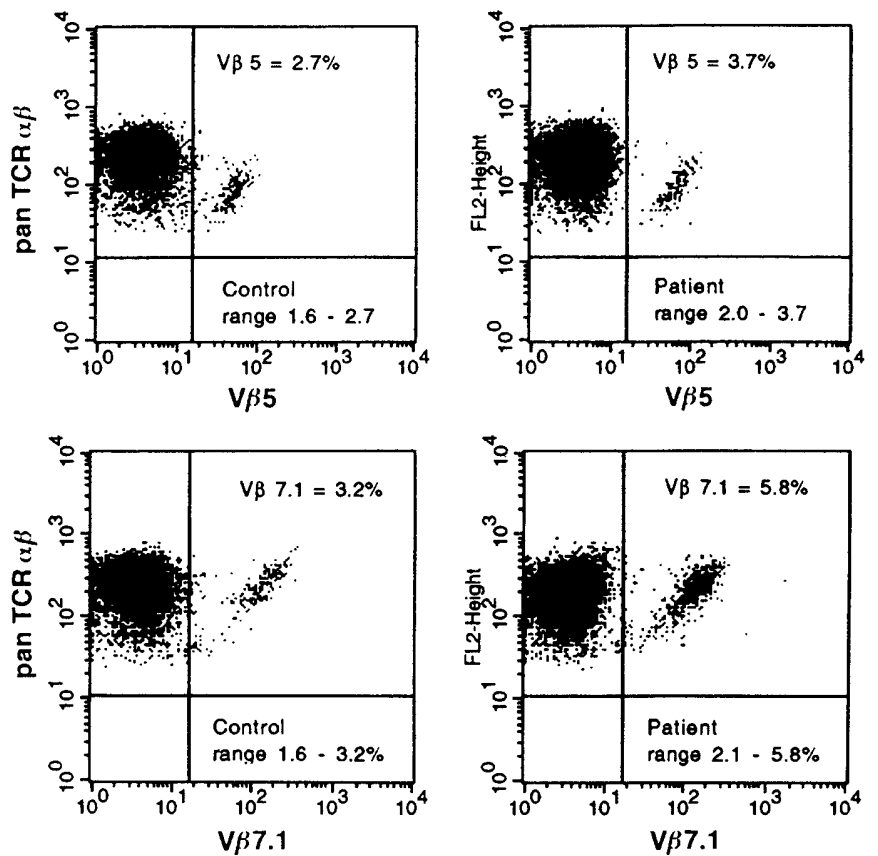

Fig. 2. Flow cytometry analysis of PBMC from one representative, recently-diagnosed diabetic patient (total $n=23$ ) and one control subject (total $n=13$ ) stained with FITC-conjugated monoclonal antibody against $\mathrm{V} \beta 7.1$ chain (clone ZOE) and PE-conjugated monoclonal antibody against pan-TCR $\alpha \beta$, by analysing live gated populations of lymphocytes. The proportion of T cells bearing V $\beta 7.1$ chain is expressed as a percentage of TCR $\alpha \beta^{+}$cells within the analysis gates. Shown are the highest value and range of $\mathrm{V} \beta 7.1^{+} \mathrm{T}$ cells detected in patients and control subjects. Frequency of $\mathrm{V} \beta 5^{+} \mathrm{T}$ cells is shown as an example of TCR V $\beta$ chains that did not change substantially between diabetic patients and control subjects

of the recently-diagnosed diabetic patients (Table 2) with that of their appropriate HLA-DR-matched and DQ-matched control subjects. The HLA-matched subjects did not reveal any expansion of the TCR $V \beta 7$ gene family (Fig.3). Again, values of $\mathrm{V} \beta 7$ mRNA expression were significantly higher in the recently-diagnosed diabetic patients than in HLA-matched control subjects $(p=0.009)$. Moreover, amongst the randomly chosen control population, nine subjects carried HLA-haplotypes conferring with a high risk of Type I diabetes (controls No. $4 ; 11 ; 16 ; 19 ; 25-29)$ but did not show increased percentage of expression of $V \beta 7$ gene transcripts.

Among the converters, expression of another gene family, $V \beta 13.1$, also tended to be higher than the mean value calculated amongst the control group. All four patients showed decreased expression of this gene family after the onset of the disease (Table 3 ).

Three of the high-risk subjects (all adults) showed values of $V \beta 7$ higher than those detected among the age-matched control group at all time points (data not shown). In these subjects, $V \beta 7$ values were above the upper limit of the appropriate control group $(10.5 \%)$ and this prevalence of skewed $V \beta 7$ was sig-
Table 3. Time-course analysis of TCR $V \beta 7$ and 13.1 gene expression in four converters

\begin{tabular}{lccc}
\hline & $V \beta 7 \%$ & $V \beta 11 \%$ & $V \beta 13$ \\
\hline CONVERTER No. 1: HLA-DRB1*03, 04; DQA1*0301, \\
DQB1*0201, 0302 \\
-40 months & 12 & 1.5 & 10.5 \\
-28 months & 13.3 & 1.4 & 8.3 \\
-24 months & 14.2 & 1.6 & 10 \\
-14 months & 16.1 & 1.3 & 9.9 \\
-10 months & 10.6 & 1.5 & 6.9 \\
-7 months & 14.4 & 1.1 & 8.7 \\
-3 months & 12.3 & 1.4 & 8.3 \\
-2 months & 14.1 & 1.4 & 7.5 \\
+ 8 months & 11.2 & 1.8 & 5.8
\end{tabular}

CONVERTER No. 2: HLA-DRB $1 * 03,04$; DQ1A*0301, 05; DQB1*0201, 0302

$\begin{array}{lllc}-40 \text { months } & 11.4 & 2.2 & 9.6 \\ -13 \text { months } & 10.9 & 2.8 & 7.4 \\ -11 \text { months } & 13.6 & 2.3 & 11 \\ -5 \text { months } & 13.6 & 1.8 & 10.4 \\ +2 \text { months } & 13.3 & 1.7 & 8.5 \\ +24 \text { months } & 13.6 & 1.4 & 5\end{array}$

CONVERTER No. 3: HLA-DRB1*04, 08; DQA1*0301, 04; DQB1*0302, 0402

$\begin{array}{lrrr}-19 \text { months } & 18.4 & 1.1 & 11.7 \\ \text {-Onset } & 12.8 & 1.6 & 10.3 \\ +32 \text { months } & 19.2 & 0.8 & 7.4 \\ +84 \text { months } & 6.3 & 1.2 & 5.5\end{array}$

CONVERTER No. 4: HLA-DRB1*03, 04; DQA1*0301, 05; DQB1*0201, 0302

\begin{tabular}{lllc}
-12 months & 16 & 1.5 & 9.6 \\
-1 month & 16 & 2 & 10.7 \\
-Onset & 12.2 & 1.9 & 9 \\
+3 months & 10.4 & 1.4 & 7 \\
CONTROLS $(n=16)$ & $5.1 \pm 1.6$ & $1.9 \pm 1.2$ & $6.4 \pm 1.1$ \\
\hline
\end{tabular}

Analysis of TCR $V \beta 7$ and 13.1 gene families in PBMC from four converters. The relative abundance of $\mathrm{T}$ cells carrying each $V \beta$ gene transcript is expressed as a percentage of corrected ratios. For each of these subjects, four to nine blood samples were available at several time points, before $(-)$ and after $(+)$ the onset of Type I diabetes. TCR $V \beta 11$ values are shown as an example of $V \beta$ family whose expression did not considerably change throughout the entire period. The mean $( \pm \mathrm{SD})$ values of TCR $V \beta 7,11$, and 13.1 gene families of normal agematched control subjects are also shown

nificantly higher compared with the control subjects $(p<0.05)$. The fourth subject showed a decreased value of $V \beta 7$ in a blood specimen drawn 8 years after the first sample (from $15.5 \%$ to $6.3 \%$ ). This patient, who was GAD autoantibody positive and ICA-512 autoantibody negative on both occasions, showed decreased ICA values at the second time-point (from 40 to $10 \mathrm{JDF}$ units) which contrasted with the stability of these titres in the other three subjects. The percentage of the $V \beta 13.1$ gene family expression measured in these high-risk subjects tended to be higher than those measured in the control group.

The TCR $V \beta$ repertoire was also analysed in PBMC from patients who were suffering from diabetes from 2 to 14 years. In this analysis, long-standing diabetic patients showed mean values of $V \beta 7$ 


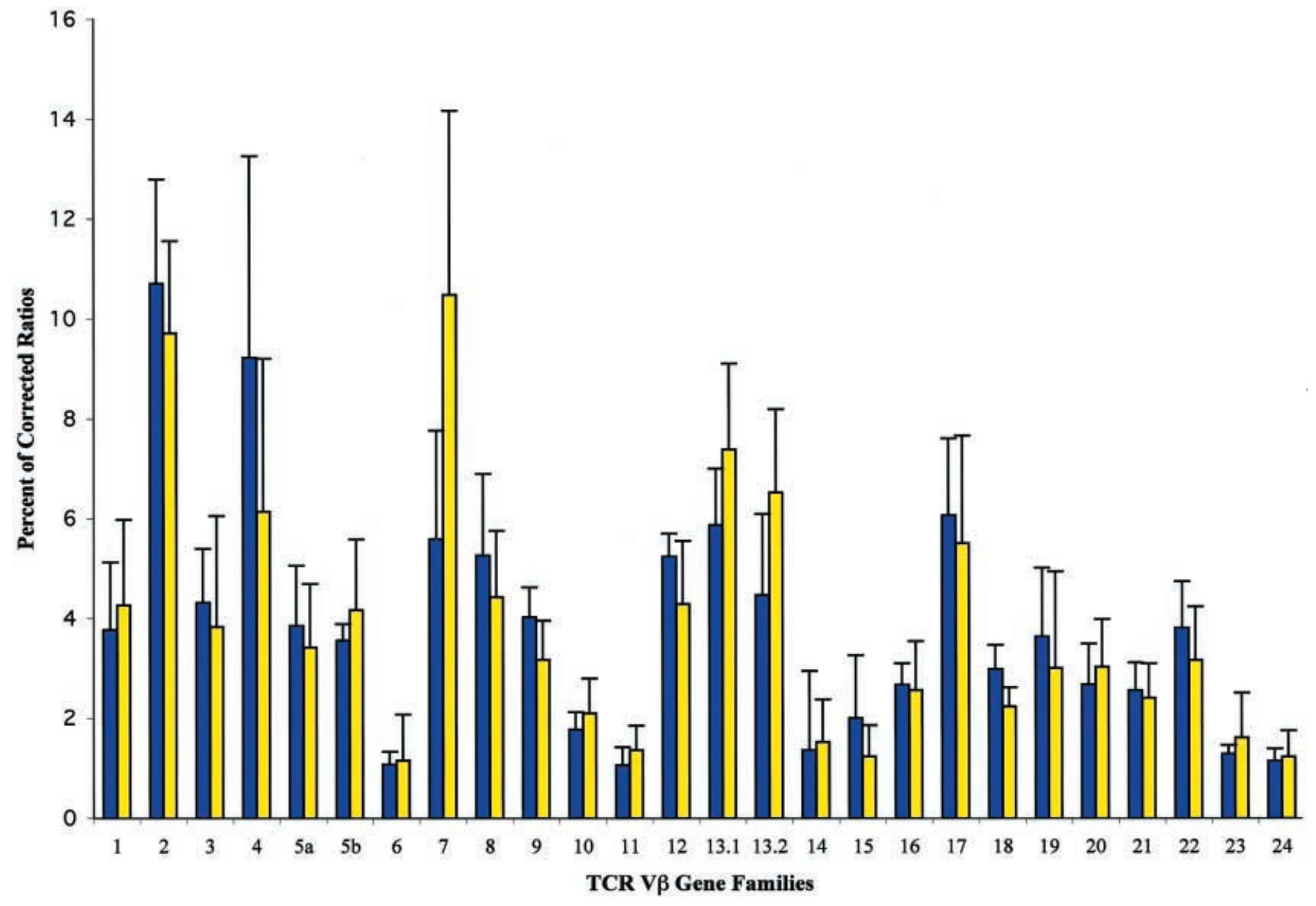

Fig. 3. Analysis of TCR $V \beta$ repertoire in PBMC from recentlydiagnosed diabetic patients $(\square, n=23)$ and their HLA-matched control subjects $(\square, n=6)$. The value of each TCR $V \beta$ is expressed as a mean percentage $( \pm \mathrm{SD})$ of corrected ratios. In HLA-matched control subjects, TCR $V \beta$ expression by $\mathrm{T}$ cells in the peripheral blood was heterogeneous and, in contrast to diabetic patients, no $V \beta 7$ gene family expansion was observed $(p=0.009)$

$(9.7 \% \pm 2.4)$ that were statistically different from those detected in the control group $(5.1 \% \pm 1.6)$ $(p<0.005)$ (Fig. 4). In $79 \%$ of these patients (11 of $14)$, the percentage of TCR $V \beta 7$ was above the upper limit of the control subjects $(8.3 \%)$ and this prevalence of skewed $V \beta 7$ was significantly higher than in the control group $(p<0.005)$. For seven of these patients, blood samples were also available at the onset of diabetes showing mean values of $V \beta 7$ of $12.3 \% \pm 3.1$ $(p<0.005$ compared with the control subjects) (Fig. 4).

In vitro PBMC stimulation with CVB-infected HeLa cell lysates. Flow cytometry analysis of the TCR repertoire of PBMC from 13 normal donors cultured for 9 days with CVB-infected HeLa cell lysates showed variable degrees of expansion of pan-TCR $\alpha \beta^{+}$T cells carrying the $\mathrm{V} \beta 7.1$ chain in the majority of the sub- jects tested (8 of 13) when compared with their PBMC cultured with uninfected-HeLa cell lysates. Whereas expression of this $\mathrm{V} \beta$ family increased up to 4 times in the PBMC of different donors, the testing of other $\mathrm{V} \beta$ families (e.g., $\mathrm{V} \beta 5$ ) did not show any changes in percentage of positives. The value for the frequency of pan-TCR $\alpha \beta^{+}$T cells carrying the $\mathrm{V} \beta$ 7.1 and the $\mathrm{V} \beta 5$ chains in 3 representative donors is shown in Figure 5. Moreover, we found that PBMC from four donors cultured with CVB-infected HeLa cells showed higher frequency of pan-TCR $\alpha \beta^{+} \mathrm{T}$ cells carrying the $\mathrm{V} \beta 13.1$ chain (data not shown). Only one donor's PBMC did not show increase of either $\mathrm{V} \beta 7.1^{+}$or $\mathrm{V} \beta 13.1^{+} \mathrm{T}$ cells.

EV antibodies and presence of EV-RNA in the sera of the subjects studied. Serological analysis for the presence of $\operatorname{IgA}$ and $\operatorname{IgG}$ class antibodies against a CVB4-antigen and a synthetic EV-peptide antigen in the patients recently diagnosed with Type I diabetes did not show statistical differences in terms of frequency of subjects that were seropositive and in the concentrations of $\operatorname{IgG}$ and $\operatorname{IgA}$ class antibodies as compared with the appropriate control group. Acute EV infections, with presence of IgM or EV-RNA, or both, in the serum, were detected with the same frequency in recently-diagnosed diabetic patients and 


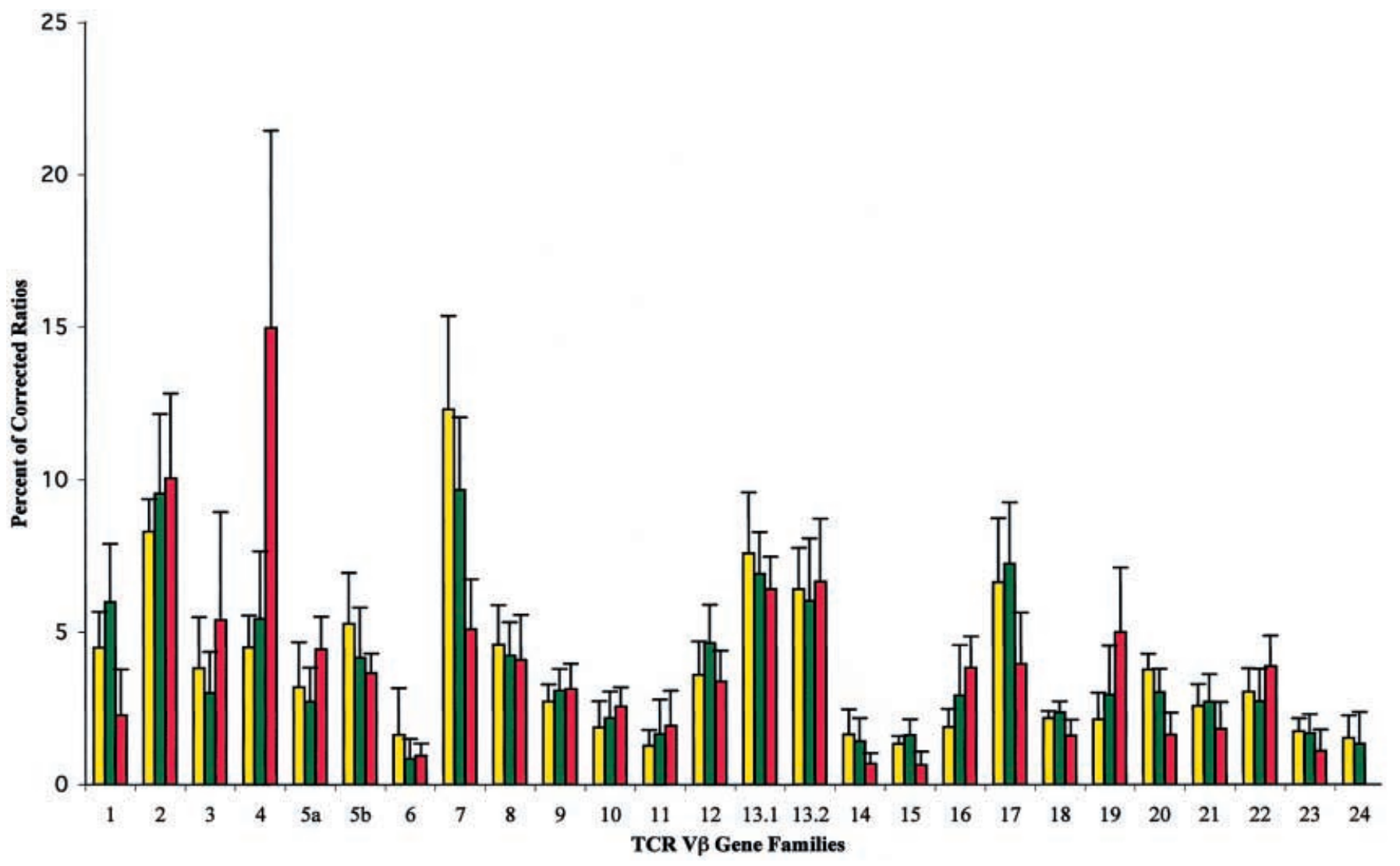

Fig. 4. Analysis of TCR $V \beta$ repertoire in PBMC from Type I diabetic patients at onset $(\square)$ and after 2 to 14 years $(\square$, after 7.2 years \pm 3.4 ). The value of each TCR $V \beta$ is expressed as a mean $( \pm \mathrm{SD})$ percentage of corrected ratios described in Materials and methods. The mean $( \pm \mathrm{SD})$ values of TCR $V \beta$ gene families from normal control subjects $(\square, n=16)$. Longstanding diabetic patients showed mean values of $V \beta 7$ that were significantly different from those detected in the control subjects $(p<0.005)$. Samples from these patients analysed at the onset of the disease showed significantly higher values of $V \beta 7$ ( $p<0.005$ to the control subjects)

control subjects (data not shown). This result was expected because the majority of kindergarten and school children are equally exposed to such an ubiquitous virus.

Analysis of the sera of the four converters in the time-course study showed, however, the presence of multiple acute EV-infections, defined by at least a twofold increase in IgA or IgG, or both, class antibodies to CVB4 and/or by IgM positivity or presence of viremia (Table 4). In the first converter, evidence of three acute infections was observed approximately at 14, 7 and 2 months before the onset of clinical diabetes, with the presence of EV-RNA in the serum from the first infection. The second converter had one acute infection approximately 5 months before overt diabetes indicated by both IgG and IgM responses. Evidence of an acute infection was also observed in con- verter No. 3, though the increase in antibody titres did not quite reach the twofold increase, as indicated in the criteria used to define the presence of acute EV-infections in the follow-up study (Table 4). Of note, converter No. 1, for example, for whom we could analyse more time-points before onset, the occurrence of acute infections is temporally related with an increase in circulating TCR $V \beta 7^{+}$T cells (Fig. 6). We detected that in this converter EV-RNA coincided with the highest expression of TCR $V \beta 7$ (at $<14$ months before the onset of diabetes) (Table 4, Fig. 6). In converter No. 2 two acute EV infections (detected by IgM antibodies) in a period of two years was associated with persistently high expression of $V \beta 7$ almost without detectable oscillation. In converter No. 3 occurrence of acute EV infection was also associated with $V \beta 7$ increase (Tables 3, 4). Because the specimens tested were collected at 3 to 6 months intervals and sometimes at even longer intervals, it was not possible to unequivocally show how close the TCR repertoire and CVB infection coincided. Converter No. 4 did not show evidence of acute infections. In this patient the IgG titre constantly remained, however, very high during the entire observation period (Table 4).

The IgA or IgG, or both, class antibodies were also detected in the sera from high-risk subjects and longstanding diabetic patients showing previous EV infections (data not shown). 


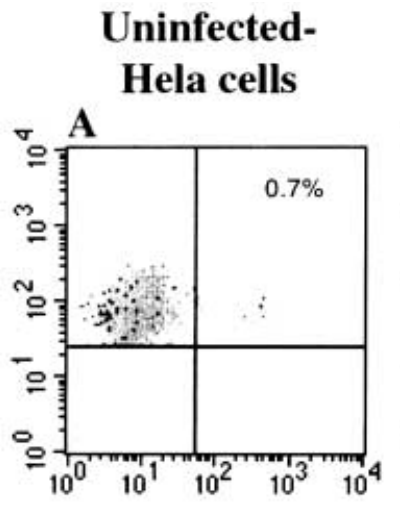

\section{CVB - infected Hela cells}
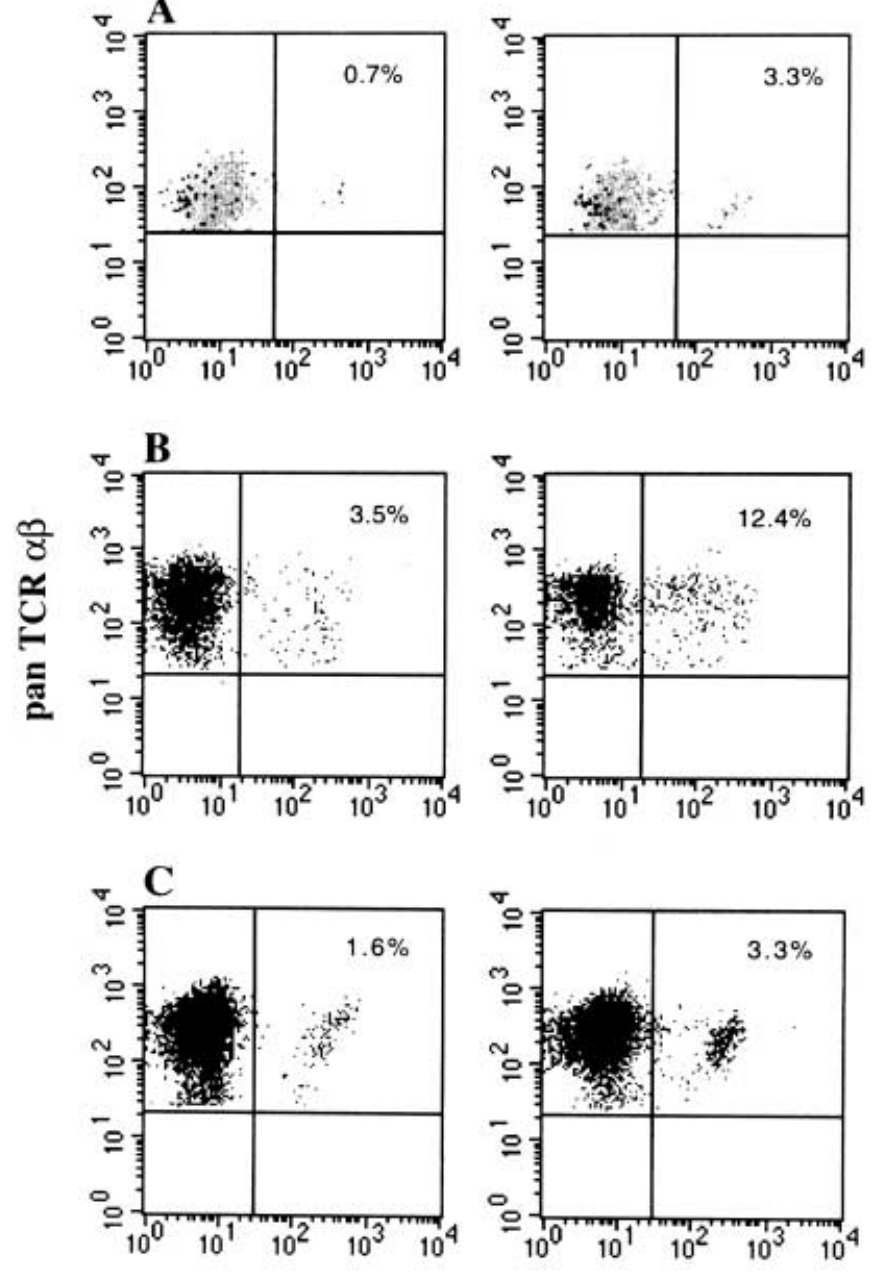

V $\beta 7.1$

Fig.5. Flow cytometry analysis of PBMC from three representative normal donors $(\mathbf{A}, \mathbf{B}, \mathbf{C})$ cultured with CVB-uninfected and CVB-infected Hela cell lysates for 9 days. The proportion of $\mathrm{T}$ cells bearing $\mathrm{V} \beta 7.1$ chain is expressed as a percentage of TCR $\alpha \beta^{+}$T cells within the live gated population of lymphocytes. Shown are the values of $\mathrm{V} \beta 7.1^{+} \mathrm{T}$ cells detected in PBMC cultured with CBV-uninfected and CVB-infected HeLa cell lysates. Frequency of $\mathrm{V} \beta 5^{+} \mathrm{T}$ cells is also shown as an example of TCR $\mathrm{V} \beta$ chain that did not show any change between the two culture conditions

\section{Discussion}

Numerous studies have indicated the role of infectious agents in the pathogenesis of Type I diabetes inducing, accelerating, or enhancing newly formed or already present autoimmune responses. One of the hypotheses is that microbial infections might break self-tolerance and trigger activation of autoreactive $\mathrm{T}$ cells. Activated T cells, in turn, destroy the target
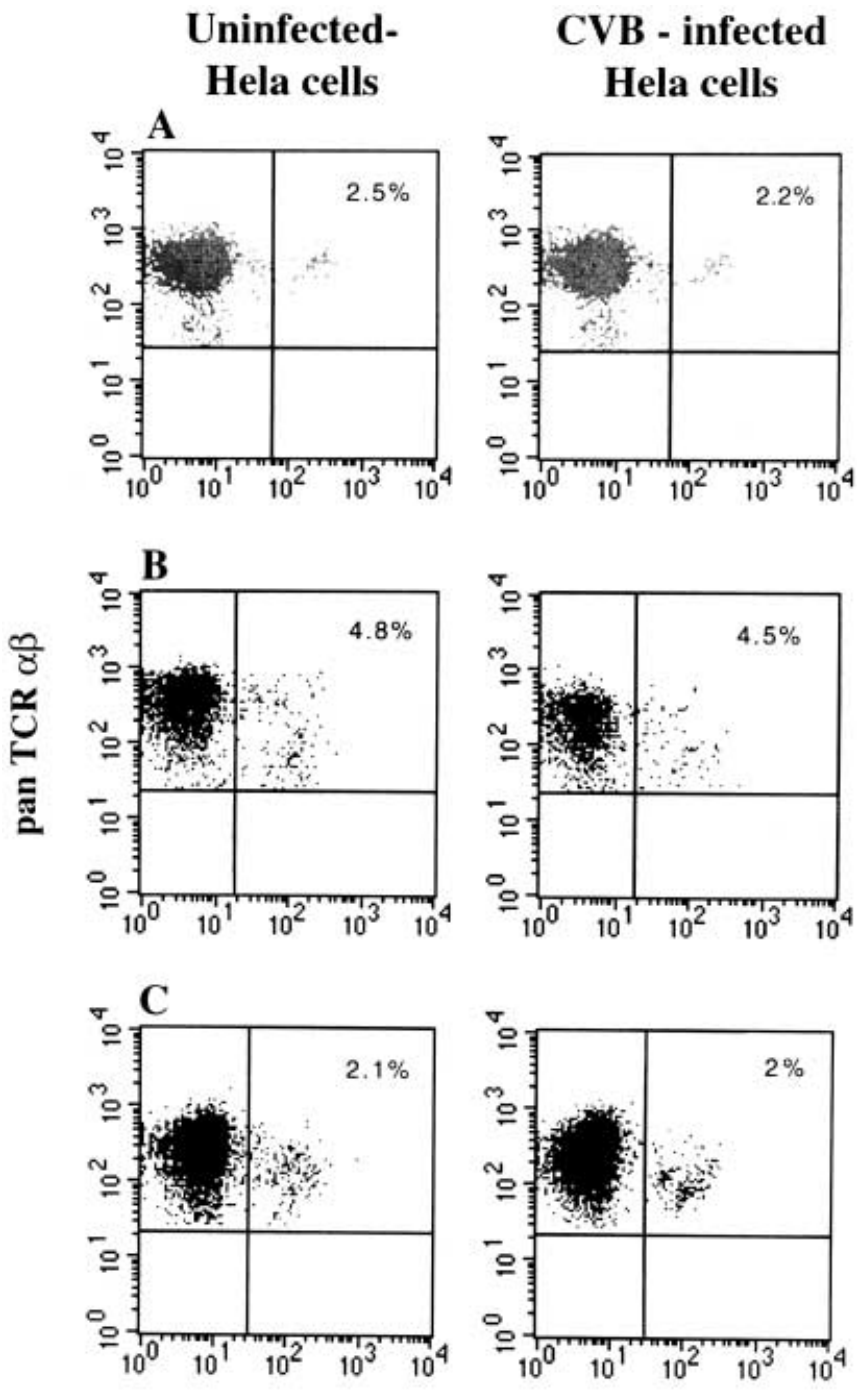

V $\beta 5$

cells harboring the self-antigen, causing organ damage and loss of function [45].

Another hypothesis is based on the evidence that the increase in total $\mathrm{T}$ cell numbers associated with viral infections, is caused by the virally-mediated production of cytokines that activate bystander $\mathrm{T}$ cells, rather than to a specific antigen (or autoantigen) or the MHC molecule complex recognition [31].

We observed a preferential usage of the TCR $V \beta 7$ gene family in the peripheral blood of patients recently diagnosed with Type I diabetes by RT-PCR. Analysis of cell surface protein expression by flow cytometry also showed a higher percentage of circulating $\mathrm{V} \beta 37.1 \mathrm{~T}$ cells in recently-diagnosed diabetic patients compared with control subjects. Such quantitative bias in the $V \beta$ repertoire was also detected years before the clinical onset of the disease in four subjects who had been prospectively followed for months or years before the development of Type I diabetes. A blood sample available seven years after 
Table 4. IgA, IgG and IgM class antibody titres against enterovirus (EV) antigens and presence of EV-RNA in converters to Type I diabetes

\begin{tabular}{|c|c|c|c|c|c|c|}
\hline & $\begin{array}{l}\text { EV-IgG } \\
\text { (synthetic peptide) }\end{array}$ & $\begin{array}{l}\text { EV-IgA } \\
\text { (synthetic peptide) }\end{array}$ & CVB4-IgG & CVB4-IgA & $\operatorname{IgM}$ & RNA \\
\hline $\begin{array}{l}\text { Converter No. } 1 \\
-40 \text { months } \\
-28 \text { months } \\
-24 \text { months } \\
-14 \text { months } \\
-10 \text { months } \\
-7 \text { months } \\
-3 \text { months } \\
-2 \text { months } \\
+8 \text { months }\end{array}$ & $\begin{array}{r}12 \\
12 \\
9 \\
6 \\
7 \\
7 \\
3 \\
\mathbf{3} \\
\mathbf{1 6}\end{array}$ & $\begin{array}{r}14 \\
8 \\
5 \\
4 \\
\mathbf{3} \\
\mathbf{4 1} \\
3 \\
3 \\
5\end{array}$ & $\begin{array}{l}27 \\
26 \\
25 \\
21 \\
24 \\
20 \\
12 \\
\mathbf{1 4} \\
\mathbf{3 2}\end{array}$ & $\begin{array}{l}34 \\
16 \\
15 \\
12 \\
\mathbf{1 5} \\
\mathbf{4 5} \\
14 \\
12 \\
21\end{array}$ & & + \\
\hline $\begin{array}{l}\text { Converter No. } 2 \\
-40 \text { months } \\
-13 \text { months } \\
-11 \text { months } \\
-5 \text { months } \\
+24 \text { months }\end{array}$ & $\begin{array}{r}64 \\
40 \\
\mathbf{4 7} \\
\mathbf{1 0 5} \\
94\end{array}$ & $\begin{array}{l}33 \\
21 \\
22 \\
28 \\
38\end{array}$ & $\begin{array}{r}92 \\
78 \\
\mathbf{8 7} \\
\mathbf{3 1 3} \\
161\end{array}$ & $\begin{array}{l}62 \\
39 \\
48 \\
79 \\
88\end{array}$ & $\begin{array}{l} \\
++ \\
+\end{array}$ & \\
\hline $\begin{array}{l}\text { Converter No. } 4 \\
-12 \text { months } \\
-1 \text { months } \\
\text { Onset } \\
+3 \text { months }\end{array}$ & $\begin{array}{r}61 \\
96 \\
85 \\
103\end{array}$ & $\begin{array}{r}8 \\
10 \\
11 \\
10\end{array}$ & $\begin{array}{l}172 \\
176 \\
168 \\
162\end{array}$ & $\begin{array}{l}16 \\
17 \\
19 \\
17\end{array}$ & & \\
\hline
\end{tabular}

The value for each IgA and IgG class antibody is expressed in enzyme immunoassay units (EIU). IgM and RT-PCR data are shown as categorical variables and are expressed as $+/-$. In bold, is shown the presence of acute $\mathrm{EV}$ infections in sequential samples shown as a twofold or greater increase in antibody value. Converter No. 3 had a marginal increase in CVB4-IgA which was highly suggestive for acute enterovirus infection

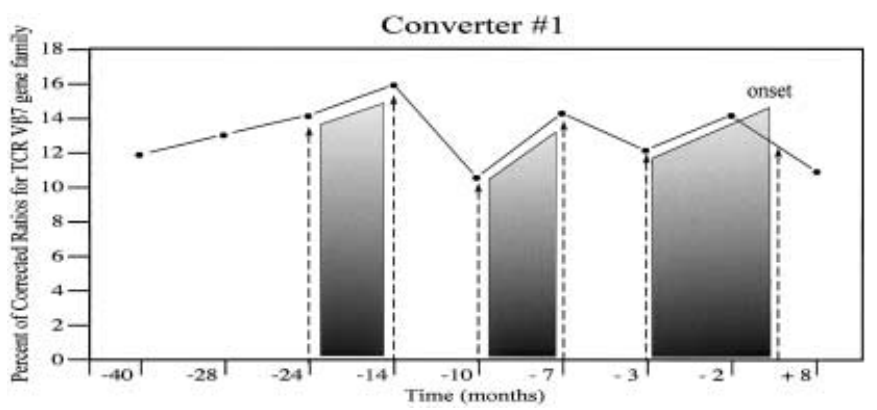

Fig. 6. Association of acute enterovirus infections with increase in $V \beta 7$ gene transcript in converter No. 1 for whom a large number of samples before onset of diabetes was available. Blood specimens collected sequentially during the prediabetic phase were tested for TCR $V \beta$ gene expression and the corresponding sera for the presence of antibodies against several different EV serotypes and EV-RNA. The Y axis indicates the percent of TCR $V \beta 7$ gene family. The $\mathrm{X}$ axis indicates the time-points (in months) when blood was collected before (-) and consequent to appearance of overt diabetes. Arrows represent evidence of acute infections and shaded traits show increase of $V \beta 7$ gene expression occurring at the time of infection (see Table 4) the onset of the disease subsequently showed that the expression of $V \beta 7$ decreased dramatically. In these patients, another family, $V \beta 13.1$, tended to be higher at the onset of the disease than in the control group and decreased more rapidly than $V \beta 7$ after the onset of the disease. We concluded that the activation of autoreactive T-cell clones is mediated by a mechanism which is not very specific (because more than one $\mathrm{V} \beta$ chain is involved, i.e., $\mathrm{V} \beta 7$ and $\mathrm{V} \beta 13.1$ ) yet certainly not totally aspecific (the two chains involved are always $\mathrm{V} \beta 7$ or $\mathrm{V} \beta 13.1$ or both). A possible immunologic mechanism involving a superantigen was suggested previously $[37,40]$ but other slightly different explanations can also be considered $[31,32]$. Apart from the true mechanism involved, it seems evident that in the majority of the cases studied, the expression of the $V \beta 7$ gene was skewed more pronouncedly than $V \beta 13.1$, so that quantitative variations of $V \beta 7$ were more easily detectable than those of $V \beta 13.1$. This difference in quantity also explains why variations of $V \beta 13.1$ in the converters (for whom we test the TCR repertoire at different time-points) could actually be detected, whereas in new-onset patients (for whom we frequently can only test one sample) the increase in 
$V \beta 13.1$ gene expression, although present, did not reach statistical significance. Thus, because the skewing of $V \beta 13.1$ was, in all cases studied, quantitatively lower than the skewing of $V \beta 7$, the $V \beta 13.1$ increase became more rapidly undetectable over time than the rise in $V \beta 7$. Because the evaluation of the various $V \beta$ families is a relative ascertainment of TCR $\beta$ chain gene usage expressed as a percentage of the total, smaller increases (e.g., $V \beta 13$ ) are more difficult to define than larger increases (e.g., $V \beta 7$ ). In long-standing Type I diabetic patients, values of $V \beta 7$ were slightly lower as compared with those at the onset of the disease but were still statistically higher than in normal subjects. The TCR repertoire analysis on our young control subjects showed an expansion of the $V \beta 4$ gene family. This gene family showed the highest variability among different subjects, possibly representing a population of $\mathrm{T}$ cells easily activated in young children, whose activation, however, quickly disappears over time.

The observation of a preferential $V \beta 7$ gene expression in peripheral blood of diabetic patients is in contrast to previous reports where the TCR $V \beta$ repertoire was found to be heterogeneous and where there was no consistent pattern of $V \beta$ expression that differentiated diabetic patients from subjects that were not affected [46, 47]. The reason for this probably depends on many factors, including the number of subjects analysed, patient heterogeneity and technical differences. Larger studies are needed to assess whether a bias in the TCR $V \beta$ expression truly characterizes pre-diabetic and diabetic patients.

The skewing of the TCR $V \beta$ repertoire is not only related to the presence of certain HLA alleles because nine of the control subjects carrying HLA-haplotypes conferring high risk to diabetes did not show the same TCR repertoire. Moreover, the analysis done on healthy subjects HLA-DR-matched and DQ-matched to the diabetic patients did not show expansion of either $V \beta 7$ or 13.1 gene families.

We previously reported the presence of a T-cell repertoire bias with overexpression of $V \beta 7$ gene family among the T cells infiltrating the islets of Langerhans of patients suffering from Type I diabetes [37]. Our results indicate that a preferential usage of the same $V \beta$ gene families can also be detected amongst the circulating $\mathrm{T}$ cells of diabetic patients. This suggests that the selective use of TCR genes in the periphery reflect an on-going infiltration within the affected tissue possibly mediated by T cells sharing the same autoreactive TCRs.

The CVB infections have been linked to Type I diabetes once a CVB4 strain was isolated from the pancreas of a diabetic child [28]. So far, reports have associated several different EV with pre-diabetic autoimmune episodes and with the onset of overt diabetes $[4,5,10,12-19]$, although the pathway by which EV could actually induce diabetes in humans is not understood very well.

The analysis of the sera from our recently-diagnosed Type I diabetic patients, showed that the numbers of subjects who were positive for EV-antibodies and EV-RNA was not statistically different than in the control groups. We anticipated these data because EV are agents of the common cold causing infections in kindergarten and school children, as reported previously [23-25]. In the longitudinal study of the four converters, however, where serum samples were available for testing every 3-6 months, multiple, sequential acute infections and viremia were detected. In particular, acute infections were observed in samples collected months before the clinical onset of diabetes. Other evidence of sequential acute EV infections before onset of Type I diabetes was described recently $[4,48]$. These data further emphasize the concept that longitudinal prospective studies on sera from diabetic patients taken at short intervals are necessary when looking for evidence of acute EV infections. Our results confirmed that the timing of EV infections play a critical part in the development of diabetes, as shown in the NOD mouse [32] and, more recently, in humans [13].

Although more Type I diabetic patients need to be analysed in prospective studies, we speculate that a history of environmental factors (i.e., Coxsackievirus infections) cause an activation of autoreactive $\mathrm{T}$ cells bearing certain $V \beta$ gene families already present in pre-diabetic subjects. In vitro, exposure of PBMC from certain healthy donors to lysates of HeLa-cells infected with CVB, was capable of selectively activating $V \beta 7^{+}$and $V \beta 13.1^{+} \mathrm{T}$ cells. These results agree with previously published data showing that variable degrees of expansion of $V \beta 7^{+}$and $V \beta 13.1^{+}$are found among proliferating and recently activated $\left(\mathrm{CD}^{6} 9^{+}\right.$and/or $\left.\mathrm{CD} 71^{+}\right) \mathrm{T}$ cells from both healthy control subjects and diabetic patients cultured with CVB-infected cell lysates [40, 49, 50]. The presence of increased percentage of TCR $V \beta 7$ gene expression at the moment of acute EV-infections was observed in at least two of the diabetic patients. Results obtained in the mouse also support this general hypothesis [31].

In short, we presented data showing an expansion of T cells bearing preferential TCR $V \beta$ gene families in the peripheral blood of Type I diabetic patients. This T-cell expansion was not solely HLA-related, it was already somewhat higher than in healthy control subjects months before overt diabetes, it was evident at the time of clinical onset and persisted for years. Also, enteroviral analysis on the sera of these subjects showed signs of acute infections months before overt diabetes. These results, with the evidence that CVB can induce preferential TCR $V \beta$ activation, support the hypothesis that EV is aetiologically important in the development of Type I diabetes by acceler- 
ating, if not initiating the process of autoimmune beta-cell destruction.

Acknowledgements. We are indebted to K. Riley and M. Smith from the Endocrinology Division of Children's Hospital of Pittsburgh for making blood samples from diabetic patients promptly available; Dr D. Finegold for providing blood samples from control children; M. and S. Pietropaolo for carrying out GAD and ICA-512 antigen radioimmunoassays and P. Hnidka for editing the manuscript. This study was supported in part by National Institutes of Health grant R01 No. DK 24021 and grants from the Juvenile Diabetes Foundation International (JDFI).

\section{References}

1. Eisenbarth GS (1986) Type I diabetes mellitus: a chronic autoimmune disease. N Engl J Med 314: 1360-1368

2. Olmos P, A'Hern R, Heaton DA et al. (1988) Significance of the concordance rate for Type I (insulin-dependent) diabetes in identical twins. Diabetologia 31: 747-750

3. Lo SS, Tun RY, Hawa H, Leslie RD (1991) Studies of diabetic twins. Diabetes Metab Rev 7: 223-238

4. Hyöty H, Hiltunen M, Knip M et al. (1995) A prospective study of the role of Coxsackie B and other enterovirus infections in the pathogenesis of IDDM. Diabetes 44: 652-657

5. Rothwell PM, Staines A, Smail P, Wadsworth E, Mckinney P (1996) Seasonality of birth of patients with childhood diabetes in Britain. BMJ 312: 1456-1457

6. Dahlquist CG, Ivarsson S, Lindberg B, Forsgren M (1995) Maternal enteroviral infection during pregnancy as a risk factor for childhood IDDM. A population-based case-control study. Diabetes 44: 408-413

7. Szopa TM, Titchener PA, Portwood ND, Taylor KW (1993) Diabetes mellitus due to viruses some recent developments. Diabetologia 36: 687-695

8. Trucco M, LaPorte R (1995) Exposure to superantigens as an immunogenetic explanation of type I diabetes mini-epidemics. J Pediatr Endocrinol Metab 8: 3-10

9. Gamble DR (1980) The epidemiology of insulin-dependent diabetes with particular reference to the relationship of virus infection to its etiology. Epidemiol Rev 2: 49-70

10. Barrett-Connor E (1985) Is insulin-dependent diabetes mellitus caused by Coxsackievirus B infection? A review of epidemiologic evidence. Rev Infect Dis 7: 207-215

11. Hiltunen M, Hyoty H, Knip M et al. (1997) ICA seroconversion in children is temporally associated with enterovirus infection. J Infect Dis 175: 554-560

12. Roivainen M, Knip M, Hyoty H et al. (1998) Several different enterovirus serotypes can be associated with prediabetic autoimmune episodes and onset of overt IDDM. J Med Virol 56: 74-78

13. Lönnrot M, Korpela K, Knip M, Ilonen J et al. (2000) Enterovirus infection as a risk factor for $\beta$-cell autoimmunity in a prospectively observed birth cohort. Diabetes 49: 1314-1318

14. Gamble DR, Taylor KW, Cumming H (1973) Coxsackie B viruses and diabetes. BMJ 4: 260-262

15. Clements GB, Galbraith DN, Taylor KW (1995) Coxsackie $B$ virus infection and onset of childhood diabetes. Lancet 346: 221-223

16. Nairn C, Galbraith DN, Taylor KW, Clements GB (1999) Enterovirus variants in the serum of children at the onset of Type 1 diabetes mellitus. Diabet Med 16: 509-513
17. Juhela S, Hyoty H, Lonnrot M, Roivainen M, Simell O, Ilonen J (1998) Enterovirus infections and enterovirus specific T-cell responses in infancy. J Med Virol 54: 226-232

18. King ML, Shaikh A, Birdwell D, Voller A, Banatvala JE (1983) Coxsackie-B-virus specific IgM responses in children with insulin-dependent (juvenile-onset; type 1) diabetes mellitus. Lancet i: 1397-1399

19. Banatvala JE, Schernthaner G, Schober E et al. (1985) Coxsackie B, mumps, rubella and cytomegalovirus specific IgM responses in patients with juvenile-onset insulin-dependent diabetes in Britain, Austria and Australia. Lancet i: $1409-1412$

20. Juhela S, Hyoty H, Hinkkanen A et al. (1999) T cell responses to enterovirus antigens and to $\beta$-cell autoantigens in unaffected children positive for IDDM-associated autoantibodies. J Autoimmun 12: 269-278

21. Juhela S, Hyöty H, Roivainen M et al. (2000) T-cell responses to enterovirus antigens in children with type 1 diabetes. Diabetes 49: 1308-1313

22. Rewers M, Atkinson M (1995) The possible role of enteroviruses in diabetes mellitus. In: Rotbart HA (ed) Human Enterovirus Infections. American Society for Microbiology, Washington, pp. 353-385

23. Orchard TJ, Atchison WR, Becker D et al. (1983) Coxsackie infection and diabetes. Lancet 631: 1983

24. Eberhardt MS, Wagener DK, Orchard TJ et al. (1985) HLA heterogeneity of insulin-dependent diabetes mellitus at diagnosis. Diabetes 34: 1247-1252

25. Hefand RF, Gary HE Jr, Freeman CYet al. (1995) Serologic evidence of an association between enteroviruses and the onset of Type 1 diabetes mellitus. J Infect Dis 172: 1206-1211

26. Yoon JW, London WT, Curfman R, Brown RL, Notkins AL (1986) Coxsackie virus B4 produces transient diabetes in non human primates. Diabetes 35: 712-716

27. Toniolo A, Onodera T, Jordan G, Yoon JW, Notkins AL (1982) Virus-induced diabetes mellitus. Glucose abnormalities produced in mice by the six members of the Coxsackie B virus group. Diabetes 31: 496-499

28. Yoon JW, Austin M, Onodera T, Notkins AL (1979) Virusinduced diabetes mellitus: Isolation of a virus from the pancreas of a child with diabetic ketoacidosis. New Engl J Med 300: 1173-1179

29. Andreolotti L, Hober D, Hober-Vandenberghie C et al. (1997) Detection of coxsackie B virus RNA sequences in whole blood samples from adult patients at the onset of type 1 diabetes mellitus. J Med Virol 52: 121-127

30. Tian J, Lehmann PV, Kaufman DL (1994) T cell cross-reactivity between coxsackievirus and glutamate decarboxylase is associated with murine diabetes susceptibility allele. J Exp Med 180: 1979-1984

31. Horwitz MS, Bradley LM, Harbertson J, Krahl T, Lee J, Sarvetnik N (1998) Diabetes induced by Coxsackie virus: Initiation by bystander damage and not molecular mimicry. Nat Med 4: 781-785

32. Serreze DV, Ottendorfer EW, Ellis TM, Gauntt CJ, Atkinson MA (2000) Acceleration of type 1 diabetes by a Coxsackievirus infection requires a preexisting critical mass of autoreactive $\mathrm{T}$ cells in pancreatic islets. Diabetes 49: 708-711

33. Bottazzo GF, Florin-Christensen A, Doniach D (1974) Islet-cell antibodies in diabetes mellitus with autoimmune polyendocrine deficiencies. Lancet ii: 1279-1282

34. Lipton RB, Kocova M, LaPorte RE et al. (1992) Autoimmunity and genetics contribute to the risk of insulin-dependent diabetes mellitus in families: islet cell antibodies and HLA DQ heterodimers. Am J Epidemiol 136: 503-512 
35. Verge CF, Gianani R, Kawasaki E et al. (1996) Prediction of type I diabetes in first-degree relatives using a combination of insulin, GAD, and ICA512bdc/IA-2 autoantibodies. Diabetes 45: 926-933

36. Brooks-Worrell BM, Starkebaum GA, Greenbaum C, Palmer JP (1996) Peripheral blood mononuclear cells of insulin-dependent diabetic patients respond to multiple islet cell proteins. J Immunol 157: 5668-5674

37. Conrad B, Weidmann E, Trucco G et al. (1994) Evidence for superantigen involvement in insulin-dependent diabetes mellitus aetiology. Nature 371: 351-355

38. Faas SJ, Menon R, Braun ER, Rudert WA, Trucco M (1996) Sequence-specific priming and exonuclease-released fluorescence detection of HLA-DQB1 alleles. Tissue Antigens 48: 97-112

39. Rudert WA, Braun ER, Faas SJ, Menon R, Jaquins-Gerstl A, Trucco M (1997) Double-labeled fluorescent probes for 5 ' nuclease assays: purification and performance evaluation. Biotechniques 22: 1140-1145

40. Luppi P, Rudert WA, Zanone MM et al. (1998) Idiopathic dilated cardiomyopathy: a superantigen-driven autoimmune disease. Circulation 98: 777-785

41. Luppi P, Trucco M (1996) Superantigens in insulin dependent diabetes mellitus. In: MacDonald HR (ed) Seminars in Immunopathology, Springer International, Heidelberg, 17: 333-362

42. Weidmann E, Whiteside TL, Giorda R, Herberman RB, Trucco M (1992) The T cell receptor $\mathrm{V} \beta$ usage in tumor-infiltrating lymphocytes and blood of patients with hepatocellular carcinoma. Cancer Res 52: 5913-5920
43. Lönnrot M, Sjöroos M, Salminen K, Maaronen M, Hyypiä T, Hyöty H (1999) Diagnosis of entero- and rhinovirus infections by RT-PCR and time-resolved fluorometry with lanthanide chelate labelled probes. J Med Virol 59: 378-384

44. Kappler J, Kotzin B, Herron L et al. (1989) V $\beta$-specific stimulation of human T cells by Staphylococcal Toxins. Science 244: 811-813

45. Oldstone MB (1998) Molecular mimicry and immune-mediated diseases. FASEB J 12: 1255-1265

46. Wong S, Wen L, Hibberd M, Millward A, Demain A (1994) Analysis of the peripheral T-cell receptor $\mathrm{V} \beta$ repertoire in newly diagnosed patients with type I diabetes. Autoimmunity 18: 77-83

47. Malhotra U, Spielman R, Concannon P (1992) Variability in T cell receptor $\mathrm{V} \beta$ usage in human peripheral blood lymphocytes. J Immunol 149: 1802-1808

48. Lonnrot M, Knip M, Roivainen M, Koskela P, Akerblom HK, Hyoty H (1998) Onset of Type 1 diabetes mellitus in infancy after enterovirus infections. Diabet Med 15: 413-434

49. Luppi P, Alexander A, Bertera S, Noonan K, Trucco M (1999) The same HLA-DQ alleles determine either susceptibility or resistance to different coxsackievirus-mediated autoimmune diseases. J Biol Regul Homeost Agents 13: $14-26$

50. Varela-Calvino R, Peakman M (1999) T cell responses to Coxsackievirus $\mathrm{B}$ and $\mathrm{T}$ cell receptor $\mathrm{V} \beta$ selection. Fourth Immunology of Diabetes Society Congress (Abstract), p. 65 